\title{
Emigracioni potencijal mladih u Srbiji
}

\author{
DOI: https://doi.org/10.11567/met.36.2.2 \\ UDK: $314.15-053.81$ \\ 316.644-053.81]:314.15 \\ Prethodno priopćenje \\ Primljeno: 1.2.2021. \\ Prihvaćeno: 1.3.2021.
}

Milica Todorović

Beograd, Srbija

milicageo123@gmail.com

Vanja Javor

Beograd, Srbija

vanjajavor@yahoo.com

Nevena Radić

Beograd, Srbija

nevence93@gmail.com

\section{REZIME}

Promene obima, pravaca, regionalnih specifičnosti, kao i motiva za preseljavanje u Republici Srbiji su došle do punog izražaja na početku 21. veka. U uslovima negativnih demografskih trendova, emigracija mladog, reproduktivno i radno sposobnog stanovništva predstavlja jedno od vitalnih pitanja daljeg razvoja države. Imajući u vidu da je kategorija mladog stanovništva osnovni demografski resurs jednog društva, središnja tema ovog rada odnosi se na stavove, namere i motive mladih prema migracijama. U cilju prezentovanja regionalnih specifičnosti izuzetno heterogenog prostora Srbije, analiza je sprovedena u tri jedinice lokalne samouprave - Gradu Užicu, Gradu Leskovcu i Gradu Zaječaru, primenom fokusgrupnog istraživanja u populaciji učenika završne godine srednje škole (149 učenika podeljenih u 15 grupa). Dobijeni rezultati ukazuju na visok nivo spremnosti učenika da se po završetku školovanja isele iz Srbije. Kao dominantni push faktori izdvajaju se oni koji pripadaju ekonomskoj sferi - ostvareni prihodi, životni standard i mogućnosti za profesionalno napredovanje. U nedostatku pouzdanih statističkih i empirijskih podataka o preseljavanju stanovništva, prezentovani rezultati mogu predstavljati značajno polazište u kreiranju mera i aktivnosti populacione politike prema migracijama.

KLJUČNE REČI: migracije, mladi, stavovi, namere, motivi, Srbija

\section{UVOD}

Migracije stanovništva kao kompleksan, dinamičan i teško predvidiv fenomen, svrstavaju se na početku 21. veka u red društvenih pojava koje okupiraju naučnu i sveukupnu pažnju javnosti, te su prepoznate kao prvorazred- 
na determinanta održivog razvoja privrede i društva, od lokalnog preko regionalnog do nacionalnog nivoa (Šantić i Antić, 2019). ${ }^{1}$ U skladu sa tim, javlja se potreba za dubinskim naučnim istraživanjima i stručnim diskusijama koje bi vodile boljem razumevanju proučavane problematike i ukazivanju na njena ograničenja i potencijale.

Poslednjih nekoliko decenija na globalnom nivou zabeležen je značajan porast broja mladih lica koja su uključena u migracione tokove. Prema podacima Ujedinjenih nacija (2019), oko 38 miliona međunarodnih migranata je mlađe od 20 godina, dok je njih 84 miliona mlađe od 30 godina. Sa druge strane, broj mladih koji učestvuju u unutrašnjim preseljavanjima je u kontinuiranom porastu (Roman i Vasilescu, 2016). Na to ukazuju i istraživanja Gallup World Poll (2013-2015) koja otkrivaju da je migracioni potencijal veći kod populacije starosti 15-29 godina u poređenju sa ostalim starosnim grupama. Uz to, rezultati su pokazuli da oko 31,7\% mladih izražava želju za emigracijom, 5,1\% planira emigraciju, dok je 1,7\% u procesu iseljavanja (Belmonte i sur., 2020).

Bez obzira da li je reč o unutrašnjim ili spoljašnjim migracionim tokovima mladog stanovištva, faktori koji na njih utiču su u osnovi veoma slični i vezani za nezadovoljstvo opštim uslovima života. Međutim, shodno demografskim, ekonomskim i sociokulturnim specifičnostima pojedinih regiona, razlikuju se grupe dominantnih faktora koji utiču na konačnu odluku o preseljavanju (GMG, 2014). Stavovi i namere o migracijama stanovništva na prostoru Srbije sagledani u više naučno-istraživačkih studija (Mojić i Petrović, 2013; Bobić i sur., 2016; KOMS, 2018; Popadić i sur., 2019; Šantić i Antić, 2019; YOUMIG, 2019; Šantić, 2020; Petrović, Brčerević i Šaranović, 2020) ukazuju na dominaciju ekonomske grupe faktora. Kao najvažniji faktori ove vrste determinisani su sledeći: nemogućnost zapošljavanja, neadekvatna visina ličnog dohotka i nizak životni standard.

Ovaj rad se oslanja na prethodna istraživanja i nastoji produbiti stečena znanja o migracionom potencijalu mladih. Cilj rada je osvetljavanje fenomena preseljavanja kroz analizu stavova, namera i motiva za donošenje odluka o emigraciji učenika završnih razreda srednjih škola u Srbiji. Nakon uvodnog dela, rad pruža uvid u teorijski okvir istraživanja, prezentuje analizu metodoloških propozicija i diskusiju empirijskih rezultata, kao i zaključna razmatranja i preporuke.

1 Ovaj rad podržan je u okviru projekta Migration, Integration and Governance Research Centre (MIGREC) koji finansira Evropska unija u okviru Horizon 2020 Programa istraživanja i inovacija, u skladu sa Sporazumom o finansiranju br. 857261. 


\section{TEORIJSKO-METODOLOŠKI OKVIR ISTRAŽIVANJA}

Grupa ekonomskih i obrazovnih faktora predstavlja dominantne razloge intenziviranja migracionih tokova mlade populacije, te su veoma važna tematska celina u domenu savremenih izučavanja prostorne pokretljivosti stanovništva (Makni, 2011; Heckert, 2015; Van Mol, 2016; Mujić i Zaimović Kurtović, 2017; Duplantier i sur., 2017; Wasuge, 2018; Cazzuffi i Fernández, 2018; Kazemi i sur., 2018; Potočnik i Adamović, 2018; IOM, 2019; Dibeh, Fakih i Marrouch, 2018; Bakina i sur., 2019; Ikuteyijo, 2020). Dominantna grupa faktora koji utiču na odluku o preseljavanju tesno je povezana sa nivoom društveno-ekonomskog razvoja zemlje porekla. Tako se u zemljama u razvoju kao primarni faktori izdvajaju oni ekonomske prirode - nedostatak osnovnih materijalnih sredstava za život, nezaposlenost i nemogućnost napredovanja u karijeri, nezadovoljstvo ekonomskom situacijom, profesijom, primanjima, ali i kvalitetom života uopšte. Sa druge strane, istraživanja sprovedena u razvijenim delovima sveta ${ }^{2}$ ukazala su na značaj obrazovanja u oblikovanju migracionih obrazaca, kao i na to da su visokoobrazovana lica u većoj meri uključena u migracioni proces u odnosu na ostatak populacije (Duplantier i sur., 2017; Semela i Cochrane, 2019; Lulle, Janta i Emilsson, 2019; Milasi, 2020). Treba imati u vidu da mladi, pogotovo iz grupe zemalja u razvoju, dolaskom u državu destinacije neretko obavljaju niskokvalifikovane poslove, bez obzira na stepen obrazovanja (King i sur., 2016).

Pored društveno-ekonomskih i političkih prilika, na migracione namere mladog stanovništva značajno utiču i individualni motivi (UN, 2013). Naime, utvrđeno je da prilikom donošenja odluke mladih članova o migraciji značajnu ulogu ima porodica (Asis i Battistella, 2013; Semela i Cochrane, 2019), kao i migrantske mreže koje oblikuju migracione tokove preko širenja informacija o potencijalnim destinacijama, mogućnostima na tržištu rada, kao i prevazilaženju prepreka koje mogu biti izazvane preseljavanjem (Elbadawy, 2011; King i sur., 2016; Serbeh i Adjei, 2020). Takođe, jedan od najčešćih razloga za preseljavanje mladog stanovništva uslovljen je spajanjem porodica ili emigracijom celokupne porodice (King i sur., 2016).

U skladu sa predmetom i zadacima istraživanja, a sve u cilju dobijanja relevantnih podataka, rad je zasnovan na fokusgrupnom istraživanju. Kao značajna kvalitativna metoda u savremenoj praksi društvenih nauka, fokus grupa podrazumeva diskusiju među namenski odabranim članovima grupe o temi od važnosti koja je unapred određena (Morgan, 1997; Krue-

2 Usp. npr. rezultate projekta Youth Mobility: Maximizing Opportunities for Individuals, Labor Markets and Regions in Europe, H2020-EU (https://www.ymobility.eu/). 
ger i Casey, 2000). Iako ne postoji formalno pravilo o optimalnom broju učesnika, Jennings (2005) ukazuje da najbolje rezultate postižu fokus grupe koje imaju najviše 10-12 članova. Značaj fokus grupe se ogleda u dubljem razumevanju pojave koja se izučava, s obzirom na to da ovaj model rada omogućava da učesnici iznesu jasne stavove i da pritom razmene iskustva sa ostalim članovima, što nije slučaj sa drugim metodama (Nyumba i sur., 2018; Zapata-Barrero i Yalaz, 2018).

Rad je utemeljen na podacima dobijenim naučno-istraživačkim projektom pod nazivom "Istraživanje stavova i namera stanovništva o preseljavanju $i$ utorđivanje uticaja migracija na demografsko starenje u četiri jedinice lokalne samouprave, u cilju formulisanja preporuka za kreiranje mera populacione politike", sprovedenog u aprilu i maju 2019. godine. Analiza je bazirana na podacima fokusgrupnog istraživanja sprovedenog $\mathrm{u}$ tri jedinice lokalne samouprave - u Gradu Leskovcu, Gradu Užicu i Gradu Zaječaru. Izabrani su regionalni centri koji se nalaze u južnom, zapadnom i istočnom delu Srbije, i koji najbolje prezentuju heterogenost društveno-ekonomske razvijenosti i migracionih obrazaca na prostoru Srbije. Grad Užice se svrstava u kategoriju najrazvijenijih jedinica lokalne samouprave, $\mathrm{u}$ kojima se bez obzira na postojanje značajnog demografskog i privrednog potencijala, u novije vreme intenziviraju emigracioni procesi. Grad Zaječar decenijama unazad predstavlja tradicionalno emigraciono područje sa ekonomskog aspeka, Grad Leskovac pripada grupi slabije razvijenih područja (Vlada Republike Srbije, 2014) u kojima su nakon dugovremenih unutrašnjih migracionih tokova u novije vremene intenzivirana i emigraciona kretanja usmerena ka inostranstvu.

Budući da izabrana kvalitativna metoda istraživanja posmatra grupu kao glavnu jedinicu analize, potrebno je da članovi odabrane grupe dele bar jednu važnu karakteristiku (Bagnoli i Clark, 2010; Frisina, 2018), što su u ovom slučaju učenici završne godine srednje škole, koji su rođeni ili koji borave na teritoriji navedenih lokalnih samouprava. Fokus grupe su organizovane u medicinskim školama i gimnazijama, dok je u Gradu Zaječaru i Gradu Leskovcu istraživanje sprovedeno i u tehničkoj školi (slika 1). Značaj uključivanja učenika srednjih stručnih škola (medicinske i tehničke škole) $\mathrm{u}$ istraživanje, ogleda se u pojavi emigracije velikog broja mladih koji nakon završetka navedenih škola život nastavljaju u inostranstvu. Poslednjih godina je naročito primećen odliv medicinskih radnika, varioca i vozača u Nemačku, ali i ka drugim državama Zapadne Evrope. Sa druge strane, odabir učenika iz gimnazija je u vezi sa činjenicom da se u njima školuju učenici koji žele da nastave školovanje na višem novou, te je pretpostavka da će kod njih stavovi i namere o preseljavanju biti manje izraženi. 
Slika 1. Šema terenskog istraživanja

Figure 1. Research scheme

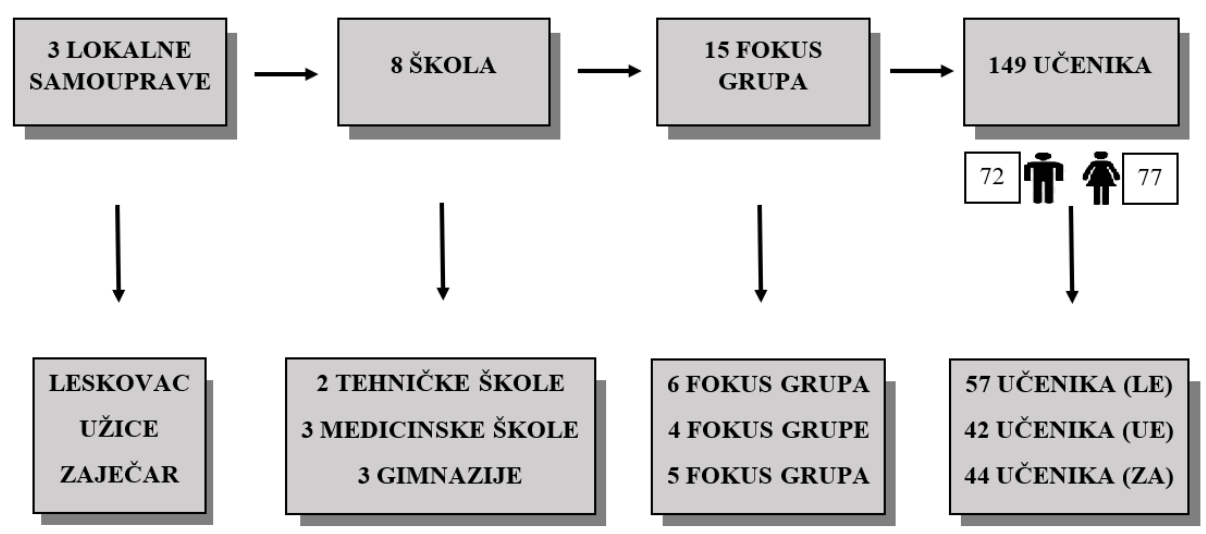

Prilikom istraživanja realizovano je ukupno 15 fokusgrupnih intervjua (Leskovac - 6; Užice - 4; Zaječar - 5) u kojima je učešće uzelo 149 učenika (Leskovac - 57; Užice - 42; Zaječar - 50). Sve fokus grupe su trajale u proseku oko 90 minuta i održane su u prostorijama navedenih škola uz odobrenje direktora i školskih pedagoga. Svi ispitanici su u trenutku sprovođenja istraživanja imali 18 ili 19 godina, dok je u pogledu polne strukture neznatno više bilo pripadnica ženskog pola (77 u odnosu na 72 pripadnika muškog pola). Učenici nisu imali migraciono iskustvo, ali je veliki broj njih aktivan $\mathrm{u}$ transnacionalnom migracionom prostoru, s obzirom na to da imaju nekog člana porodice, rođaka ili prijatelja u inostranstvu sa kojim na različite načine ostvaruju kontakt - što je bilo od velikog značaja za istraživanje.

\section{REZULTATI I DISKUSIJA}

Značaj i aktuelnost tematike migracije mladih prepoznali su učesnici fokus grupa koji su pokazali entuzijazam i u isto vreme ozbiljno pristupili diskusiji. Razgovoru je prethodilo pojašnjenje o predmetu istraživanja, načinu funkcionisanja fokus grupe i anonimnosti samog postupka. Radna atmosfera u svakoj od fokus grupa bila je pozitivna i podsticajna, što je omogućilo da učenici iskažu stavove bez ustručavanja. Diskusija se zasnivala na interaktivnom pristupu. Ispitanici su izražavali stavove kroz konstruktivnu razmenu mišljenja uz poštovanje specifičnosti odgovora svakog pojedinca. Iako su ispitanici individualno davali odgovore, primećen je značajan stepen podudarnosti određenih stavova. Definisan vremenski okvir fokus grupe omogućio je da se svaki segment istraživanja adekvatno obradi. 
Razmatrajući stavove prema migracijama, ustanovljeno je da je generalno mišljenje učenika da se na početku 21. veka intenziviralo iseljavanje stanovništva iz Republike Srbije, a kao dominantan razlog istaknuta je nepovoljna ekonomska situacija. Većina učenika se slaže sa konstatacijom da iseljavanje stanovništva predstavlja proces koji negativno utiče na sveukupni razvoj Srbije. Sa druge strane, izvesni učenici ističu pozitivne strane migracije i naglašavaju da one mogu poboljšati život pojedinca i porodice, i na taj način predstavljati potencijal i resurs za dalji razvoj države.

Za samu državu migracije jesu negativan proces, ali mi moramo da se snalazimo i od nečega živimo. Ta ista država nam nije obezbedila uslove da ostanemo. Zašto da ostanemo ako nam ne odgovara $i$ ako su uslovi bolji na nekom drugom mestu? (Leskovac, medicinska škola)

Dominantni su stavovi da odluka o preseljavanju mora da se zasniva na slobodnoj proceni pojedinca i da svako ko želi da se iseli treba da realizuje svoju odluku budući da uvek postoji mogućnost da se vrati u državu porekla. Iako pojedini učenici smatraju da pre donošenja odluke o iseljavanju treba uzeti u obzir i pozitivne i negativne strane emigracije, poruke koje bi većina uputila mladima koji žele da odu iz Srbije u najvećem broju slučajeva su afirmativne.

Vratiti se uvek može, ali ako ne probamo nešto novo, ne znamo ni šta smo propustili. Život je svakako kratak. (Zaječar, medicinska škola)

Utvrđivanje migracionog potencijala ispitanika predstavlja jedan od glavnih ciljeva istraživanja i osnovu dalje analize rada. Rezultati istraživanja pokazali su da većina učesnika u diskusiji namerava da ostane u Srbiji, pri čemu je namera o ostanku u većoj meri naglašena kod učenika iz Grada Leskovca, što je razumljivo s obzirom na to da ovaj prostor predstavlja sredinu sa tradicionalnim porodičnim vrednostima. Sa druge strane, najizraženije emigracione namere su kod učenika iz Grada Zaječara, tradicionalno emigracionog prostora. Malobrojni učenici koji su neodlučni u svojim namerama, planiraju da ostvare svoje ciljeve u Srbiji i da se tek u slučaju neuspeha isele $u$ inostranstvo. Iako se želja da se pomogne razvoju zajednice izdvaja kao značajna determinanta ostanka, uočeno je da je vezanost za porodicu glavni faktor koji utiče na odluku o (ne)preseljavanju.

Želim da ostanem ovde zato što je ovde moj dom. Ovde sam rođena i ovde mi je porodica od koje ne želim da se razdvajam. (Užice, medicinska škola)

Ukoliko se mišljenja ispitanika posmatraju prema tipu škole, uočeno je da postoje značajne razlike. Učenici medicinskih škola u svim lokalnim samo- 
upravama su u većoj meri iskazali spremnost da ostanu u zemlji, što je suprotno opšte prisutnom trendu iseljavanja medicinskih radnika u države Evropske unije. Istraživanje je pokazalo da su učenici iz ovih škola optimističniji u odnosu na učenike drugih škola jer smatraju da je mogućnost pronalaženja posla za njihov obrazovni profil u Srbiji trenutno nešto povoljnija.

Ne želim da se iselim iz Srbije. Mislim da nakon završetka medicinske škole mogu lako da pronađem posao u struci u Srbiji. (Leskovac, medicinska škola)

Važno je istaći da učenici koji nameravaju da ostanu u Srbiju u najvećem broju slučajeva planiraju da nastave život u nekom od velikih regionalnih centara - Beogradu, Novom Sadu ili Nišu. Njihova odluka da učestvuju u unutrašnjim migracionim tokovima može se dovesti u vezu sa činjenicom da $u$ navedenim regionalnim središtima planiraju da nastave školovanje i da nakon završetka studija u njima i ostanu. Utvrđeno je da učenici iz Grada Leskovca prevashodno nameravaju da nastave školovanje u Nišu, učenici iz Grada Užica se opredeljuju za fakultete u Beogradu, dok učenici iz Grada Zaječara gotovo podjednako gravitiraju ka Beogradu i Nišu. Navedene razlike u odgovorima među učenicima iz različitih lokalnih sredina u korelaciji su sa geografskom blizinom njihovog mesta prebivališta i univerzitetskih centara.

Sagledavanjem motiva koji utiču na migracione namere mladih ustanovljeno je da faktori ekonomske prirode imaju izrazitu ulogu u procesu donošenja odluke o potencijalnoj emigraciji. Kao najučestaliji odbijajući faktor izdvaja se nepovoljna finansijska situacija u porodici. Veliki broj učenika nije zadovoljan životnim standardom svoje porodice, s obzirom na to da je samo jedan član zaposlen. Uzimajući u obzir navedeno, među ispitanicima preovlađuje mišljenje da je migracija „sredstvo” ili „oruđe” za postizanje blagostanja, kao i mogućnost za bolji život porodice. Takva razmišljanja proizilaze iz stavova učenika da bi doznake iz inostranstva koje bi slali članovi porodice bile $\mathrm{u}$ funkciji poboljšanja životnog standarda cele porodice.

Znam da neki ne bi to rekli, ali ja se ne stidim, iselio bih se jer nemam para ni ja ni moja braća. Ako bih otišao, proo bih gledao da njima pomognem i usrećim ih koliko mogu. (Zaječar, gimnazija)

Kada je reč o privlačnim faktorima, ispitanici su se u najvećem broju izjasnili da su životni standard, veće plate i adekvatniji uslovi za profesionalno usavršavanje i napredovanje $u$ inostranstvu odlučujući za potencijalnu emigraciju. U tom pogledu, učenici tehničkih škola pokazali su izraženiju sklonost ka emigraciji na veće distance, odnosno na druge kontinente, u skladu sa razvijenošću informatičke tehnologije na tim odredištima. 
Pošto planiram da se bavim programiranjem, znam da u Srbiji nemam dobru osnovu za to. Tehnologija nam kasni jedno deset godina za razvijenim svetom $i$ sve nam stiže mnogo kasnije. (Zaječar, tehnička škola)

S obzirom na značaj obrazovanja u procesu donošenja odluke o preseljavanju, posebna pažnja tokom fokusgrupnog istraživanja usmerena je na uticaj ovog faktora na potencijalnu emigraciju mladih iz Srbije. Istraživanjem je utvrđeno da obrazovanje ne predstavlja značajan faktor spoljne migracije, s obzirom na to da neznatan broj učenika planira da neposredno po završetku srednje škole nastavi školovanje u inostranstvu. Učenici koji razmišljaju da nastave školovanje u nekoj drugoj zemlji, migracije percipiraju kao mogućnost lakšeg ostanka u toj sredini. S tim u vezi se faktor obrazovanja može posmatrati komplementarno sa ekonomskim faktorima.

Planiram da se nakon što upišem fakultet prijavim za studentsku razmenu negde u inostranstvo. Naravno, tamo bih posle toga, zbog boljih ekonomskih uslova života, i ostao. (Zaječar, tehnička škola)

U diskusiji na temu najznačajnijih odbijajućih faktora, učesnici su istakli nezadovoljstvo opštim uslovima života u Srbiji. Posebno nezadovoljstvo je izraženo među ispitanicima iz Grada Leskovca. Kroz razmenu stavova u jednoj od škola u ovoj lokalnoj samoupravi, učenici su ukazali da je socijalni aspekt visoko $\mathrm{u}$ rangu faktora prilikom formiranja stavova. Oni smatraju da mladi u Srbiji lako prihvataju norme zapadne kulture dok istovremeno zanemaruju tradiciju i životne navike zemlje porekla. Sa druge strane, pojedini ispitanici ukazuju na to da se odluka o emigraciji donosi brzopleto i da $u$ tome mediji imaju veliku ulogu, ali i sam proces globalizacije koji je promenio sve sfere savremenog života. Veliki broj ispitanika kao glavne uzroke za iseljavanje navodi nefunkcionisanje države koje se ogleda kroz nepotizam i korupciju.

Pogrešan je sistem vrednosti. Izuzetno je prisutno licemerstvo i još neke druge negativne osobine koje utiču na to se društvo ne drži zajedno. Sve je veći raskol u društvu zbog tih osobina. To se desilo zbog određenih političkih poteza. (Leskovac, gimnazija)

Diskusija o potencijalnoj destinaciji učenika dovela je do zaključka da većina kao potencijalnu državu emigracije vidi neko od tradicionalnih odredišta stanovnika Srbije: Austriju, Nemačku, Francusku, SAD ili Kanadu. Prilikom izbora destinacije, učesnici su istakli presudan značaj migracionih mreža, odnosno veze sa rođacima i prijateljima u inostranstvu (slika 2). Osim toga, ispitanici su saglasni u tome da članovi porodice, prijatelji i poznanici koji 
su u inostranstvu mogu biti važna finansijska i moralna podrška tokom celokupnog procesa iseljavanja. Zahvaljujući informacijama koje dobijaju od njih, smatraju takvi ispitanici, jasnije se sagledavaju mogućnosti i uslovi života u emigraciji, što je od velikog značaja prilikom donošenja odluke o izboru potencijalne države prijema. Pojedini ispitanici naglašavaju da prisustvo rođaka i poznanika u izabranoj državi destinacije može imati veliki značaj tokom procesa integracije u novoj sredini.

Slika 2. Migrantske mreže učenika srednjih škola

Figure 2. Migrant networks of secondary school pupils

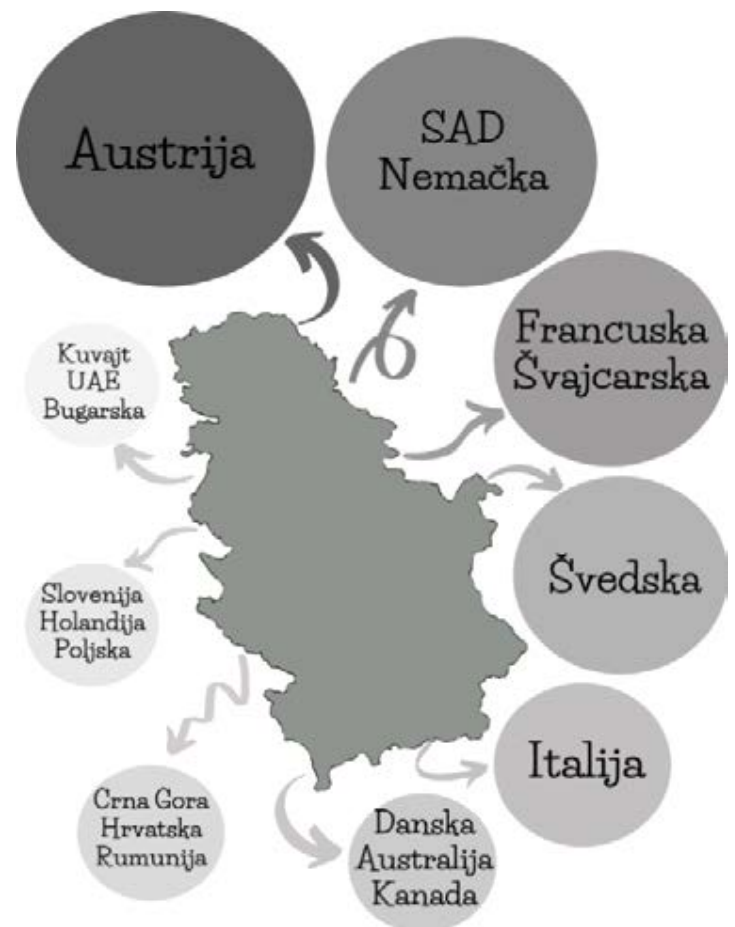

S obzirom na to da niko od ispitanika nije imao migraciono iskustvo, stav o tome kakvi su uslovi života $\mathrm{u}$ inostranstvu zasnivaju isključivo na osnovu iskustava drugih, odnosno rođaka i prijatelja. Kao najvažniju pozitivnu karakteristiku vezanu za preseljavanje, izdvajaju finansijsku sigurnost, dok su nepoznavanje jezika zemlje destinacije i teškoća u prilagođavanju različitoj kulturi i stilu života neki od negativnih aspekata.

Stric mi živi u SAD. Nije mu lako, ali ima odlične uslove za život. Njegove dve dnevnice tamo su kao prosečna plata u Srbiji. (Užice, medicinska škola) 
Na osnovu diskusija i razmene mišljanja učesnika fokus grupa, bilo je moguće kreirati određene preporuke donosiocima odluka u cilju ublažavanja iseljavanja mladih. Ispitanici su predložili niz konkretnih mera koje država treba da donese kako bi se poboljšali određeni aspekti života u Srbiji. Najčešći predlozi su iz domena ekonomske sfere, te je pored povećanja mesečnih primanja, prema mišljenju ispitanika, potrebno otvoriti veći broj radnih mesta, prevashodno za visokoobrazovana lica, s obzirom na to da se ova kategorija lica usled nemogućnosti pronalaženja posla u struci najčešće odlučuje za emigraciju. Učenici navode i da bi bilo izuzeto podsticajno da država daje određenu novčanu pomoć mladima nakon završetka fakulteta kako bi započeli sopstveni biznis (start-up) i na taj način im pruži dobru osnovu za planiranje budućeg života u Srbiji.

Potrebno je da se otvore radna mesta za mlade koji završe fakultete. Sve više se otvaraju fabrike u kojima se traži jeftina radna snaga. Treba nešto da se ponudi mladima koji imaju završen fakultet kako se ne bi više iseljavali. (Leskovac, gimnazija)

Pojedini učenici navode da su neophodne reforme $u$ pogledu obrazovnog sistema. U tom kontekstu smatraju da je potrebno poboljšati upisnu politiku na svim fakultetima u Srbiji, kako se u budućnosti ne bi dešavalo da pojedini kadrovi godinama bezuspešno traže posao u struci. Zaključak je da je neophodno uskladiti obrazovne profile sa potrebama na tržištu rada.

Treba popraviti upisnu politiku na fakultetima, da se ne dešava da imamo previše slobodnih mesta na fakultetima čiji kadrovi sutra traže posao godinama. (Užice, gimnazija)

Zanimljivo je da su ispitanici u sve tri lokalne samouprave bili jednoglasni u stavu da se previše investira u razvoj Beograda, a da je nedovoljno investicija usmereno $\mathrm{u}$ planiranje razvoja drugih lokalnih samouprava, pre svega u ruralnim sredinama. Prema njihovom mišljenju, strategije i planove budućeg razvoja različitih, veoma heterogenih delova države, treba pažljivo kreirati uvažavajući njihove specifičnosti. Na taj način bi se unapredio kvalitet života u lokalnim samoupravama, a time i oslabili push faktori. Konkretno, učenici iz Grada Užica i Grada Leskovca navode da je potrebno da se u njihovim gradovima otvori veći broj fakulteta i da bi to u određenoj meri moglo doprineti smanjenju emigracionog potencijala mladih. Učenici iz ruralnih sredina su posebno ukazali na potrebu za investiranjem u poljoprivredu i izrazili zabrinutost zbog višedecenijske depopulacije i populacionog pražnjenja ovih prostora Srbije. 
Jedna velika opština kao što je Leskovac treba da ima univerzitet. Većina mladih koji odu na studiranje se ne vrate više. Kada bismo imali univerzitet, siguran sam da bi se manje mladih odlučilo na preseljavanje. (Leskovac, gimnazija)

Treba investirati u razvoj sela, naša sela se gase. (Užice, gimnazija)

\section{ZAKLJUČAK}

Mlado stanovništvo predstavlja značajan resurs sveukupnog razvoja jedne države. U uslovima višedecenijskih negativnih demografskih trendova, emigracija mladog, reproduktivno i radno sposobnog stanovništva predstavlja jedno od vitalnih pitanja daljeg razvoja Republike Srbije. U skladu sa navedenim, osnovni cilj ovog rada bio je sagledavanje stavova i namera maturanata u tri jedinice lokalne samouprave u Srbiji - u Gradu Leskovcu, Gradu Užicu i Gradu Zaječaru, kao i utvrđivanje faktora potencijalne emigracije mladih. Uzimajući u obzir rezultate ranijih studija koji su naglasili značaj ekonomskih i obrazovnih determinanti u procesu emigracije mladih, navedeni faktori su posebno sagledani tokom realizacije fokus grupa.

Rezultati istraživanja su ukazali na relativno visok nivo spremnosti učenika da se isele iz Srbije nakon školovanja. Faktori ekonomske prirode i nezadovoljstvo opštim uslovima života izdvojeni su kao dominantni činioci u procesu potencijalne emigracije mladih. Kao odbijajući faktor najčešće se navodi nepovoljna finansijska situacija porodice, dok bolji životni standard, veći prihodi i adekvatniji uslovi za profesionalno usavršavanje i napredovanje predstavljaju ključne privlačne faktore migracije. Uz to, istraživanje je ukazalo da migracione mreže predstavljaju vrlo važan element u procesu izbora potencijalne destinacije. Sa druge strane, glavni faktor koji utiče na odluku učenika da ostanu u Srbiji je vezanost za porodicu, pri čemu većina njih planira da nastavi školovanje i život u nekom od velikih regionalnih centara i na taj način učestvuju u unutrašnjim migracionim tokovima. Interesantno je da nastavak školovanja predstavlja značajan faktor unutrašnjih migracija, dok je njegov uticaj na odluku o potencijalnoj migraciji iz Srbije gotovo zanemarujući.

Iako pojedini učenici naglašavaju da migracije mogu poboljšati život pojedinca i porodice, većinski stav je da iseljavanje predstavlja proces koji negativno utiče na sveukupni razvoj Republike Srbije. S tim u vezi učenici su predložili niz konkretnih mera u cilju ublažavanja migracionog procesa. Njihove preporuke su, pre svega, iz domena poboljšanja ekonomske situacije i uključuju povećanje mesečnih primanja, otvaranje novih radnih mesta 
(naročito za visokoobrazovana lica) i podsticanje preduzetništva mladih. Prepoznata je potreba da deo investicija bude usmeren i ka ruralnim sredinama kako bi se ublažili efekti procesa depopulacije i ekonomskog propadanja ruralnih prostora. U kontekstu unapređenja obrazovnog sistema, preporuke su da je neophodno sprovesti reforme kojima bi se obrazovni profili uskladili sa potrebama tržišta rada. Učenici u sve tri lokalne samouprave smatraju da strategije i planove budućeg razvoja treba kreirati u skladu sa specifičnostima različitih regiona.

Iako je značaj tematike migracija mladih prepoznat na akademskom nivou u Republici Srbiji, uočena je potreba za kompleksnijim sagledavanjem ovog fenomena u razvojnim i strateškim dokumentima. U vezi sa tim, neophodno je intenzivirati kvalitativna istraživanja na lokalnom, regionalnom i nacionalnom nivou, što bi omogućilo donošenje adekvatnih planova, strategija i mera populacione politike prema migracijama mladog stanovništva. $U$ tu svrhu, rezultati ovog rada mogu imati značajan doprinos i biti osnova za dalja istraživanja migracionih procesa mladih u Srbiji.

\section{LITERATURA}

Asis, M. M. B. i Battistella, G. (2013). The Filipino Youth and the Employment-Migration Nexus. UNICEF, Scalabrini Migration Center, https://www.sdgfund.org/sites/ default/files/YEM_STUDY_Philip_Youth\%2C\%20employment\%20and $\% 20$ migration.pdf (12.12.2020.)

Bagnolia, A. i Clark, A. (2010). Focus groups with young people: a participatory approach to research planning, Journal of Youth Studies, 3 (1): 101-119.

Bakina A. V., Yaremtchuk S. V., Orlova O. A. i Krasnoperova Y. V. (2019). Life Satisfaction and Migration Intention of Youth, u: Solovev, D. B. (ur.). Proceedings of the International Scientific Conference "Far East Con" (ISCFEC 2018), https://dx.doi. org/10.2991/iscfec-18.2019.158

Belmonte, M., Conte, A., Ghio, D., Kalantaryan, S. i McMahon, S. (2020). Youth and migration: an overview. Luxembourg: Publications Office of the European Union, https://doi.org/10.2760/625356

Bobić, M., Vesković Anđelković, M. i Kokotović Kanazir, V. (2016). Studija o spoljnim i unutrašnjim migracijama građana Srbije s posebnim osvrtom na mlade. Beograd: IOM.

Cazzuffi, C. i Fernández, J. (2018). Rural youth and migration in Ecuador, Mexico and Peru. Santiago: Rimisp - Latin American Center for Rural Development (Serie documento de trabajo 235, Programa Jóvenes Rurales, Territorios y Oportunidades: Una estrategia de diálogos de políticas), https://www.rimisp.org/wp-content/files_mf/1539440301D ocumentoTrabajoenproceso_RuralYouthMigration_Cazzuffi_Fernandez_2018.pdf (07.11.2020.).

Dibeh, G, Fakih, A. i Marrouch, W. (2018). Decision to Emigrate Amongst the Youth in Lebanon, International Migration, 56 (1): 5-22. https://doi.org/10.1111/imig.12347 
Duplantier, A., Ksoll, C., Lehrer, K. i Seitz, W. (2017). The internal migration choices of Ghanaian youths, https://www.wider.unu.edu/sites/default/files/DUPLANTIER\% 2C\%20Anne_paper.pdf (15.11.2020.).

Elbadawy, A. (2011). Migration aspirations among young people in Egypt: Who desires to migrate and why?, Politics and Economic Development, ERF 17th Annual Conference, Antalya, March, 20-22, 2011. https://iussp.org/sites/default/files/event call_for_papers/Youth\%20Migration\%20Aspiration\%20in\%20Egypt_elbadawy.pdf (15.11.2020.).

Frisina, A. (2018). Focus Groups in Migration Research: A Forum for "Public Thinking"? u: Zapata-Barrero, R. i Yalaz, E. (ur.). Qualitative Research in European Migration Studies. Springer Open: Cham, 189-208. https://doi.org/10.1007/978-3-319-76861-8_11

Global Migration Group (2014). Migration and Youth: Challenges and Opportunities. United Nations Children's Fund, http://jeronimocortina.com/wp-content/uploads/2017/07/ Migration-and-Youth-Challanges-and-Opportunities-Full.pdf (15.02.2021.).

Heckert, J. (2015). New perspective on youth migration: Motives and family investment patterns, Demographic Research, 33: 765-800. https://dx.doi.org/10.4054/Dem Res.2015.33.27

Ikuteyijo, L. O. (2020). Irregular Migration as Survival Strategy: Narratives from Youth in Urban Nigeria, u: McLean, M. (ur.). West African Youth Challenges and Opportunity Pathways. Gender and Cultural Studies in Africa and the Diaspora. Cham: Palgrave Macmillan, 53-77. https://doi.org/10.1007/978-3-030-21092-2_3

International Organization of Migration (2019). World Migration Report 2020. Geneva: IOM, https://publications.iom.int/system/files/pdf/wmr_2020.pdf (20.01.2021.).

Jennings, G. R. (2005). Business Research, Social Science Methods Used In, u: KempfLeonard, K. (ur.). Encyclopedia of Social Measurement. Amsterdam: Elsevier Science Publishing, 219-230. https://doi.org/10.1016/B0-12-369398-5/00270-X

Kazemi, A., Baghbanian, A., Maymand, M. M. i Rahmani, H. (2018). Contributing Factors to Migration Growth Among Iranian Students: Drivers of Migration to Malaysia, Journal of International Migration and Integration, 19 (3): 757-770. https://doi. org/10.1007/s12134-018-0567-z

King, R., Lulle, A., Morosanu L. i Williams A. (2016). International Youth Mobility and Life Transitions in Europe: Questions, Definitions, Typologies and Theoretical Approaches. Sussex: Sussex Centre for Migration Research (Working Paper 86), http://sro.sussex. ac.uk/id/eprint/61441/1/mwp86.pdf (15.11.2020.).

Krovna organizacija mladih Srbije (KOMS) (2018). Alternationi izveštaj o položaju $i$ potrebama mladih u Republici Srbiji. Beograd: KOMS, https://koms.rs/wp-content/ uploads/2018/08/Alternativni-izves\%CC\%8Ctaj-o-polo\%C5\%BEaju-i-potrebamamladih-2018.pdf (15.11.2020.).

Krueger, R. i Casey, M. (2000). Focus groups: a practical guide for applied research. Thousand Oaks: Sage.

Lulle, A., Janta, H. i Emilsson, H. (2019). Introduction to the Special Issue: European youth migration: human capital outcomes, skills and competences, Journal of Ethnic and Migration Studies. https://doi.org/10.1080/1369183X.2019.1679407

Makni, V. (2011). Student migration potential: The case of Bulgaria, South-Eastern Europe Journal of Economics, 2: 187-206. https://dx.doi.org/10.2139/ssrn.1573658

Milasi, S. (2020). What Drives Youth's Intention to Migrate Abroad? Evidence from International Survey Data, IZA Journal of Development and Migration 11 (1). https:// doi.org/10.2478/izajodm-2020-0012 
Mojić, D. i Petrović, I. (2013). Youth and Legitimacy of Social Order in Serbia: Thinking and Acting in the Direction of Emigration, Sociologija, 55 (2): 229-244. https://doi. org/10.2298/SOC1302229M

Morgan, D. L. (1997). Focus groups as qualitative research, 2nd edition. Thousand Oaks: Sage Publications. https://dx.doi.org/10.4135/9781412984287

Mujić, M. i Zaimović Kurtović, L. (2017). Masovni odlazak mladih iz BiH: Potraga za poslom ili bijeg od stvarnosti?. Sarajevo: Centar za izborne studije, https://ba.boell. org/sites/default/files/uploads/2017/09/studija-masovni-odlazak-mladih-iz-bih.pdf (05.12.2020.).

Nyumba, T., Wilson, K., Derrick, C. i Mukherjee, N. (2018). The use of focus group discussion methodology: Insights from two decades of application in conservation, Methods in Ecology and Evolution, 9: 20-32. https://doi.org/10.1111/2041-210X.12860

Petrović, P., Brčerević, D. i Šaranović, S. (2020). Migracije s istoka na zapad Evrope: Da li Srbija može da odoli naletima vetra?. Fiskalni savez Srbije, http://fiskalnisavet.rs/doc/ istrazivacki-radovi/FS_RadniDokument_20-01.pdf (12.11.2020.).

Popadić, D., Pavlović, Z.i Mihailović, S. (2019). Mladi u Srbiji 2018/2019. Beograd: Friedrich Ebert Stiftung, https://library.fes.de/pdf-files/bueros/belgrad/15295-20190411.pdf (30.10.2020.).

Potočnik, D. i Adamović, M. (2018). Iskustvo migracije i planirani odlasci mladih iz Hrvatske. Zagreb: Friedrich Ebert Stiftung, http://library.fes.de/pdf-files/bueros/ kroatien/14481.pdf (01.11.2020.).

Roman, M. i Vasilescu, M. D. (2016). Explaining the Migration Intentions Of Romanian Youth: Are Teenegers Different?, Romanian Statistical Review, 64 (4): 69-86.

Šantić, D. (2020). Leaving Serbia Aspirations, intentions and drivers of youth migration democracy and human rights. Beograd: Friedrich-Ebert-Stiftung, http://library.fes.de/ pdf-files/bueros/belgrad/16219.pdf (20.01.2021.).

Šantić, D. i Antić, М. [Шантић, Д. и Антић, М.] (ur.) (2019). Istraživanje stavova i namera stanovništva o preseljavanju i utvrđivanje uticaja migracija na demografsko starenje u četiri jedinice lokalne samouprave, u cilju formulisanja preporuka za kreiranje mera populacione politike [Истраживатье ставова и намера становништва о пресељаватьу и утврђиватье утицаја миграцчија на демографско старете у четири јединице локалне самоуправе, у цииьу формулисань препорука за креиранье мера популациионе политике]. Beograd [Београд]: Univerzitet u Beogradu - Geografski fakultet [Универзитет у Београду - Географски факултет], http://www.mdpp.gov.rs/doc/Geografski-fakultet-ISTRAZIVANJE-MIGRACIJA-2019.pdf (01.11.2020.).

Semela, T. i Cochrane, L. (2019). Education-Migration Nexus: Understanding Youth Migration in Southern Ethiopia, Education Sciences, 9 (2): 1-15. https://doi.org/10.3390/ educsci9020077

Serbeh, R. i Adjei, P. O-W. (2020). Social Networks and the Geographies of Young People's Migration: Evidence from Independent Child Migration in Ghana, Journal of International Migration and Integration, 21, 221-240. https://doi.org/10.1007/s12134019-00720-w

United Nations (2013). World youth report: Youth and migration. New York, http://www. unworldyouthreport.org/ (11.12.2020.).

United Nations (2019). International migrant stock 2019. New York, https://www. un.org/en/development/desa/population/migration/data/estimates2/estimates19. asp (05.02.2021.). 
Van Mol, C. (2016). Migration Aspirations of European Youth in Times of Crisis, Journal of Youth Studies, 19 (10): 1303-1320. https://doi.org/10.1080/13676261.2016.1166192

Vlada Republike Srbije [Влада Републике Србије] (2014). O utvrđivanju jedinstvene liste razvijenosti regiona i jedinica lokalne samouprave za 2014. godinu [О утврђивању јединствене листе развијености региона и јединица локалне самоуправе за 2014. годину], Službeni glasnik Republike Srbije, 104/2014 [Службени гласник Републике Србије, 104/2014], http://privreda.gov.rs/wp-content/uploads/2017/05/Uredba-OUtvrdjivanju-Jedinstvene-Liste-Razvijenosti-Regiona-I-JLS-Za-2014..pdf

Wasuge, M. (2018). Youth Migration in Somalia: Causes, Consequences and Possible Remedies. Mogadishu: The Heritage Institute for Policy Studies, https://reliefweb.int/sites/ reliefweb.int/files/resources/Youth-Migration-in-Somalia-1.pdf (12.12.2020.).

YOUMIG (2019). National policy recommendations for improved cooperation on youth migration - National policy recommendations, Serbia, http://www.interreg-danube. eu/uploads/media/approved_project_output/0001/33/ce9d8d886d3d00dfbc 8beef5369391f732a15d26.pdf (12.12.2020.).

Zapata-Barrero, R. i Yalaz, E. (2018). Introduction: Preparing the Way for Qualitative Research in Migration Studies. u: Zapata-Barrero, R. i Yalaz, E. (ur.). Qualitative Research in European Migration Studies. Cham: IMISCO - Springer Open, 1-8. https:// doi.org/10.1007/978-3-319-76861-8_1

\title{
Emigration Potential of Youth in Serbia
}

\author{
Milica Todorović, Vanja Javor, Nevena Radić
}

\begin{abstract}
SUMMARY
Amidst negative demographic trends, emigration of the young, reproductive and employable population is one of the vital issues for the further development of the Republic of Serbia. Hence, there is a need for in-depth academic research and expert discussions that would allow for a better understanding of the issue, while pointing out its limitations and potentials. Since the country's emigration potential is not sufficiently represented in previous research, this paper aims to shed light on the phenomenon of migration by discussing the attitudes, intentions and motives of senior-year high school students. It also aims to identify the factors for the potential emigration of young people. In line with the research subject and aims, the paper relies on the focus group method. The analysis was carried out using data from a focus-group survey conducted in three local governments - the City of Leskovac, the City of Užice and the City of Zaječar. Regional centres in the southern, western and eastern parts of Serbia were selected because they best represent the heterogeneity of its socio-economic development and migration patterns. Given that the group is the main unit of analysis within the chosen qualitative research method, the respondents had to share at least one important characteristic. In this case, they were senior-year high school students, born or residing in the mentioned cities. Focus groups were organised in Medical Schools and Grammar schools, while in the City of Zaječar and the City of Leskovac, the research was conducted in the Technical School, too. During the research, a total of 15 focus-group interviews were conducted, in which 149 students participated. All respondents were 18 or 19 years old at the time of
\end{abstract}


the survey, while in terms of gender structure, there were slightly more females (77 compared to 72 males). The participants recognised the importance and relevance of youth migration, showed enthusiasm and, at the same time, took the discussion seriously. The results showed that most of the participants intend to stay in Serbia, while also indicating a relatively high level of readiness to emigrate after finishing school. The intention to stay is more pronounced among the students from the City of Leskovac, which is understandable considering that this is an area where traditional family values are important. On the other hand, the intentions to emigrate are most frequent among students from the City of Zaječar, a traditional emigration area. Although the desire to aid the development of the community stands out as a significant determinant of staying, attachment to the family emerges as the main factor influencing the decision not to emigrate. When observing the respondents' opinions according to the type of school, significant differences were noticed. Students of medical schools in all cities have to a greater extent expressed their readiness to stay in the country, which is contrary to the generally present trend of emigration of medical workers to EU countries. The research showed that students from these schools are more optimistic than students from other schools because they believe that the prospects of finding a job for their educational profile in Serbia are currently somewhat more favourable. It is important to point out that students who intend to stay in Serbia in most cases plan to continue living in one of the large regional centers - Belgrade, Novi Sad or Niš. Their decision to participate in internal migration flows can be related to the fact that they plan to continue their education in the mentioned regional centres and to stay there after graduation. It was found that students from the City of Leskovac primarily intend to continue their education in Niš, students from the City of Užice opt for faculties in Belgrade, while students from the City of Zaječar gravitate almost equally towards Belgrade and Niš. By considering the motives that influence young people's migration intentions, it was established that economic factors have a distinct role in deciding on potential emigration. The most frequent push factor is the unfavourable financial situation in the family. When it comes to the pull-factors, the majority of respondents stated that the standard of living, higher salaries and more adequate conditions for professional development and advancement abroad are decisive for potential emigration. As to the importance of education in the process of deciding on migration, it does not appear to be a significant factor for external migration, given that a small number of students plan to continue their education abroad immediately after high school. While discussing the most significant push-factors, the participants expressed dissatisfaction with the general living conditions in Serbia. The students' discussion about the potential destination led to the conclusion that the majority see traditional destinations of the inhabitants of Serbia as potential countries of emigration: Austria, Germany, France, the USA or Canada. When it comes to the choice of a destination, the participants emphasised the crucial importance of migration networks, i.e., connections with relatives and friends abroad. Some respondents emphasise that having relatives and acquaintances in the chosen destination country can be of great importance during integration into a new environment. Although some students emphasise that migration can improve the lives of individuals and families, the majority view emigration as a process that negatively affects the overall development of Serbia. Interestingly, the respondents in all three local government units expressed a unanimous attitude that too many resources are being invested in the development of Belgrade, while insufficient investments are directed to the planning of the development of other local governments, primarily in rural areas. Based on the discussions and exchange of 
opinions of focus group participants, it was possible to create certain recommendations to decision-makers to mitigate the problem of the emigration of young people. The respondents suggested several concrete measures that the state should take to improve certain aspects of life in Serbia. Their recommendations are focused, above all, on improving the economic situation, including increased monthly incomes, creating new jobs (especially for highly educated people) and encouraging youth entrepreneurship. They recognised the need for part of the investments to be directed towards rural areas in order to mitigate the effects of depopulation and economic decline. In the context of improving the education system, the recommendations call for reforms that would align education profiles with the needs of the labour market. Students in all three local governments believe that strategies and plans for future development should be tailored to the specific needs of different regions. Although the importance of youth migration is recognised at the academic level in Serbia, this phenomenon requires a more complex analysis in development and strategic documents. In this regard, qualitative research needs to intensify at the local, regional and national levels, which would enable the adoption of adequate plans, strategies and measures of population policy towards the migration of young people. The results of this paper can contribute significantly to and serve as the basis for further research on the migration processes among young people in Serbia.

KEY WORDS: migration, youth, attitudes, intentions, motives, Serbia 